\title{
Peran Komunitas Islam dalam Menyemangati Keagamaan para Pemuda
}

\author{
Istiqomah Bekthi Utami \\ Fakultas Dakwah dan Komunikasi UIN Sunan Gunung Djati, Bandung \\ *Email : istiqomabutami129@gmail.com
}

\begin{abstract}
This study aims to find out how the work program, the constraints, the role, the success rate, and the implementation of the program conducted by Pesantren Yatim Al-Hilal in empowering orphaned resources by building the community's caring participation for abandoned orphans. Place research conducted by the author that is in Pesantren Yatim Al-Hilal Village Rancapanggung Kec. Cililin Kab. West Bandung. The method used in this research is descriptive method, with data collection technique through documentation study, observation and interview. Because the research is qualitative, the data collected is then analyzed by selecting and classifying the data in order to facilitate the conclusion. Based on the results of research conducted on this Pesantren Yatim AlHilal, the authors found out that empowerment of orphans conducted by Al-Hilal pesantren by providing human resource development by improving both social and religious knowledge, by meeting the needs of life for orphans as the realization of the success of orphans in achieving their goals and can be useful for the nation, and the country.
\end{abstract}

Keywords: Islamic Boarding; Empowerment; Orphans

\begin{abstract}
ABSTRAK
Penelitian ini bertujuan untuk mengetahui bagaimana program, kegiatan, pelaksanaan, peran dan faktor pendukung serta penghambat yang dilakukan oleh Komunitas Gerakan Pemuda Hijrah dalam menyemangati Keagamaan para Pemuda. Tempat penelitian yang dilakukan oleh penulis yaitu di Komunitas Gerakan Pemuda Hijrah yang bermarkas di Masjid Al- Lathiif Jalan Saninten No. 2 Bandung. Metode yang digunakan dalam penelitian ini adalah metode deskriptif, dengan teknik pengumpulan data melalui studi dokumentasi, observasi dan wawancara. Karena penelitian ini bersifat kualitatif, maka data yang dikumpulkan kemudian dianalisis dengan memilih dan mengklasifikasikan data tersebut supaya mempermudah dalam penarikan kesimpulan. Berdasarkan hasil penelitian yang dilakukan terhadap Komunitas Gerakan Pemuda Hijrah ini, penulis menemukan hasil bahwa komunitas Gerakan Pemuda Hijrah sangat berperan dalam menyemangati keagamaan para pemuda, terutama pengajarkan dalam hal keagamaan yang sifatnya mampu menjadikan sorang insan yang benar-benar bertakwa dan beriman kepada Allah SWT.
\end{abstract}

Kata Kunci : Komunitas; Keagamaan; Para Pemuda

\section{PENDAHULUAN}

Di Indonesia yang mayoritas penduduknya beragama Islam banyak berdiri lembaga, organisasi dan komunitas Islam yang bergerak di bidang dakwah, salah satunya bukti yaitu adanya komunitas Islam. Komunitas Islam adalah sebuah

Diterima: Pebruari 2018. Disetujui: April 2018. Dipublikasikan: Juni 2018 


\section{B. Utami,}

kelompok sosial dari beberapa individu Muslim dari berbagai latar belakang yang berbeda, umumnya memiliki ketertarikan dan tujuan yang sama untuk menyiarkan Islam.

Komunitas Islam merupakan pendidikan luar sekolah, sudah selayaknya kegiatan-kegiatan yang bernuasa Islami mendapat perhatian serta dukungan dari masyarakat terutama para pemuda, agar tercipta insan-insan yang memiliki keseimbangan antara potensi mental spiritual dan juga potensi intelektual dalam menghadapi perubahan zaman yang semakin maju.Keberadaan komunitas Islam memiliki gerakan yang berbeda-beda, sesuai dengan target marketnya masingmasing yang disesuaikan dengan kemampuan. Adapun salah satu komunitas Islam untuk pemuda adalah Komunitas Gerakan Pemuda Hijrah Bandung.

Era globalisasi ini tidak sedikit pemuda pemudi Islam yang lalai dari tujuan mereka di ciptakan oleh Allah SWT di muka bumi ini. Banyak di antara mereka yang memusatkan perhatian dan kerja kerasnya untuk meraih prestasi pendidikan, pekerjaan, dan kemampanan ekonomi semata.KomunitasGerakan Pemuda Hijrah adalah komunitas yang mengendepankan syariat Islam dan hukum-hukum Islam, memiliki misi yakni menyebarkan nilai-nilai Islam kedalam seluruh aktivitas pemuda dan pemudi Muslim Indonesia khususnya di Bandung, serta berperan aktif membendung serangan liberalisme dari barat yang di tunjukan kepada para pemuda dan pemudi Muslim melalui fun, food, fashion, dan lifestyle. Meskipun seluruh anggotanya di komunitas ini anak muda atau remaja, Pemuda Hijrah berusaha agar setiap anggotanya dapat menyebarkan virus positif dilingkungan mereka masing-masing, bukan hanya kepada anggotanya tetapi jama'ah juga.

Masa remaja merupakan masa pencarian identitas termasuk dalam hal keagamaan. Menurut riset kelompok remaja cukup rawan terhadap pengaruh ajaran agama yang dapat mendorong perilaku kekerasan (Enggera \& Berton, 2019); Namun demikian di masa ini bukan berarti tidak dapat diupayakan satu sistem pendidikan, setidaknya dalam membangun kesadaran agama (religiousity awareness)(Mansur et.all.,2018). Agama mungkin dapat melahirkan perilaku radikal seperti yang dilakukan oleh islamisis di Eropa, tapi mungkin bisa diberi alternatif lain yang mengajarkan karakter yang toleran (Baier, D. ,2013).

Penelitian yang sebelumnya oleh Siti Aminah (2014), mengamati tingkat kesadaran anggota Badan Kontak MajelisTaklim melalui usaha pembinaan agama. Perbedaan penelitian ini terfokus kepada tingkat kesadaran anggota majelis taklim terhadap pembinaan agama sedangkan penelitian penulis fokus kepada peran komunitas islam dalam menyemangati keagamaan para pemuda. Persamaan penelitian terdahulu dengan penelitian ini sama-sama tentang Keagamaan yang dilakukan oleh lembaga atau komunitas Islam.

Penelitian selanjutnya dengan judul Ita Nurhasanah (2015). Peranan Khithabah dalam meningkatkan kesadaran beragama Remaja. Perbedaan 
penelitian ini terfokus kepada peranan Khithabah terhadap meningkatan kesadaran agama remaja sedangkan penelitian penulis fokus kepada peran komunitas islam terhadap semangat keagamaan para pemuda. Persamaan penelitian terdahulu dengan penelitian ini sama-sama tentang pemahaman keagamaan terhadap generasi penerus bangsa.

Lokasi penelitian dilakukan di Komunitas Gerakan Pemuda Hijrah di pusat kota Bandung yang bermarkas di Masjid Al-Lathiif berada di Jalan Saninten No 2 Bandung Wetan, Kota Bandung, Jawa Barat 40114. Komunitas Geraka Pemuda Hijrah merupakan Komunitas Islam yang bergerak di karangan para pemuda, dengan mengumpulkan pemuda dan pemudi yang mempunyai latar belakang berandalan yang ingin merubah dirinya menjadi lebih baik (bijrah) mendekatkan dirinya kepada Allah SWT, salah satunya dengan memperbaiki akhlak dan menjunjung tinggi nilai-nilai aqidah, tauhid dan akhlak dalam kehidupan sehari-hari secara Istiqomah.

Sebagai sebuah komunitas Islam yang bergerak di kalangan pemuda latar belakang berandalan. Dari itulah pemuda harus mendapatkan pengarahan dan bimbingan untuk pembentukan kedewasaan diri yang mana diperoleh dengan pendidikan keagamaan. Memang tidak mudah dan tentu banyak kendala-kendala yang dihadapi disebabkan kurangnya pengetahuan agama dan minimnya pemuda dalam mengamalkan ajaran agama.

Adapun rumusan masalah penelitian yang dibuat Pertama, Bagaimana kegiatan Komunitas Gerakan Pemuda Hijrah Dalam Menyemagati Keagamaan para Pemuda? Kedua, Apa faktor Pendukung dan Penghambat Komunitas Gerakan Pemuda Hijrah dalam menyemangati Keagamaan para Pemuda?

Dalam melakukan penelitian ini, penulis menggunakan metode deskriptif, yakni data yang dikumpulkan berupa kata-kata, gambar, dan bukan angka-angka. Hal ini disebabkan oleh adanya penerapan metode kualitatif. Selain itu semua yang dikumpulkan berkemungkinan menjadi kunci terhadap apa yang sudah di teliti. Dengan demikian, laporan penelitian akan berupa kutipan-kutipan untuk memberikan gambaran penyajian laporan tersebut. Data tersebut mungkin dari data wawancara, catatan lapangan, foto, dokumen pribadi, catatan atau memo, dan dokumen resmi lainnya (Moleong, 2000: 4).

Jenis data yang akan digunakan dalam penelitian ini menggunakan jenis data kualitatif yaitu dengan mempertanyakan apakah kenyataan (realitas) tersebut memiliki kualitas tertentu. Penulis berharap dengan menggunakan data kualitatif, didapatkan hasil penelitian yang menyajikan data yang akurat dan digambarkan secara jelas dari kondisi sebenarnya. Disini sesungguhnya ditekankan perspektif pandangan sosio-psikologi didasarkan atas fakta. Bagaimanapun saratan utamanya adalah pada individu dengan kepribadian diri pribadi dan pada interaksi antara pendapat intern dan emosi seseorang dan tingkah laku sosialnya 
(Ikbar, 2012: 91).

\section{HASIL DAN PEMBAHASAN}

Teori yang akan dijadikan landasan dalam penelitian ini adalah teori Peran, Komunitas Islam, Keagamaan, dan Pemuda. Peran merupakan aspek dinamis kedudukan (status), apabila seseorang melaksanakan hak dan kewajibannya sesuai dengan kedudukannya, maka ia menjalankan suatu peranan.

Menurut Vanina Delobelle, pengertian dari komunitas adalah sekelompok orang yang memiliki minat yang serupa atau sama dan terdiri dari 4 faktor yakni; (1) Tempat yang disepakati bersama untuk bertemu; (2) Kebiasaan dan ritual; (3) memiliki keinginan berbagi (sharing); (4) influencer merintis sesuatu hal dan para anggota selanjutnya ikut terlibat.

Islam merupakan agama kebersihan dari cacat, kepatuhan dan perdamaian untuk memperoleh keselamatan dunia dan akhirat. Hal tersebut didasarkan atas arti harfiah Islam yang seakar dengan kata; (1) al-salam, berati kepasrahan, ketundukan, menyerahkan diri dan kepatuhan;(2) al-salm dan al-silm, berarti aman dan damai ;3) al-salm dan al-salamah, berarti bersih dan selamat dari cacat lahir maupun batin. Orang yang berislam adalah orang tunduk, patuh dan menyerahkan diri dalam melakukan perilaku yang baik, supaya di dalam hidupnya bersih lahir dan batin seta akan mendapatkan keselamatan dan kedamaian hidup di dunia dan juga di akhirat.(Kahmad D, 2006).

Kegiatan dakwah adalah sebagai proses mengajak manusia kepada $\mathrm{Al}$ Islam yang dilakukan baik secara tulisan maupun secara lisan, serta bisa juga dengan aksi sosial Islam atau dengan perbuatan, baik dalam bentuk lembagalembaga Islam sebagai wadah untuk kegiatan mengajak yang dilakukan secara sinkronisasi, kordinasi, sistematisasi tindakan dan integrasi program dengan waktu yang tersedia dan sumber daya untuk mencapai sasaran dan tujuan dakwah Islam. (AS E\& Tajiri H, 2009:11).

Menurut Agus Ahmad Safei ( 2016: 3) Pada prakteknya, kegiatan dakwah dalam Islam sesungguhnya meliputi semua demensi kehidupan manusia. Secara demikian, kegiatan budaya, politik, ekonomi, sosial, dan lain-lain dapat dijadikan kegiatan dakwah, baik dakwah Islamiyah (dakwah ila Allah) maupun dakwah jahiliyah, yakni dakwah yang menjadikan neraka sebagai pelabuhan terakhir (dakwah ila al-nar).

Seorang da'i pun harus memiliki kemampuan diri seperti pengetahuan Islam yang bersumber dari Al-Qur'an, Sunnah dan juga ilmu-ilmu keislaman lainnya, pengetahuan bahasa dan kesastraan, memahami karakter objek dakwah, memahami dasar dakwah, memahami tujuan dakwah, materi dakwah yang akan disampaikan kepada mad'u secara benar dan baik, dan metode dakwah dengan menggunakan metode dakwah yang sesuai dengan kemampuan dirinya dan dengan materi yang diberikan serta dengan situasi dan juga kondisi yang lebih 
relevan dengan objek yang dihadapi (Sukayat T, 2015: 102).

Pengembangan masyarakat merupakan sistem dakwah berupa tathwir islam, sebagai upaya pemberdayaan atau pengembangan masyarakat islam untuk mewujudkan khairu ummah yang berbasis individu muslim yang berkualitas yang dijanjikan oleh Allah akan memperoleh ridha-Nya. Tujuan ini akan dapat tercapai manakala iman, islam, dan takwa dapat ditransformasikan menjadi tata nilai dalam kehidupan individu, kelompok, maupun institusi masyarakat, karena dengan begitu manusia diposisikan pada posisi kemanusiaannya (AS E, 2011: 475).

Komunitas Islam adalah sebuah kelompok sosial dari beberapa individu Muslim dari berbagai latar belakang yang berbeda, yang pada dasarnya memiliki tujuan dan ketertarikan yang sama untuk menyiarkan Islam. Dimana Individuindividu di dalamnya memiliki kepercayaan, maksud, kebutuhan, sumber daya, resiko, preferensi serta sejumlah kondisi lain yang sama. Komunitas berasal dari bahasa latin communitas yang berarti "kesamaan", kemudian diturunkan menjadi communis yang berarti "sama", publik dibagi oleh semua atau banyak. (Wenger T, 2002: 4).

Komunitas Islam melalui gerakan dakwah memegang peranan penting dalam membangun tatanan sosial berlandasan Islam baik yang berkenaan dengan, sikap, fikrah, keyakinan, serta perilaku. Hakikat dakwah dapat dilihat dari aspek sosial, yang mempuyai arti membangun (Tathwir Islam).

Keagamaan berasal dari kata "agama" yang berawalan "ke" dan berakhiran "an”. Dalam bahasa Arab agama diterjemahkan dari kata ad-Din, ad-Din yang biasa disebut agama adalah hubungan antara makhluk dengan kholiknya. (Shihab Q M, 1996: 210).

Di dalam era globalisasi ini agama sangat penting dalam kehidupan seharihari, karena banyak manfaat dari agama.Manfaat agama secara individual artinya berkaitan dengan totalitas individu baik secara rohani maupun fisikAda tiga aspek yang berkaiatan dengan manfaat agama secara individual yakni; (1)Agama yang diimani akan menumbuhkan sikap optimis,(2) Agama menjadi pencerahan pikiran, (3) Agama yang diimani akan menimbulkan ketemtraman hati. Dan manfaat agama secara sosial berkaiatan dengan relasi-relasi kehidupan di dalam bermasyarakat dengan baik, baik seagama maupun berbeda agama, hidup tampak rukun serta harmonis, saling tolong menolong dalam kebaikan dan bertakwa, berwasiat tentang kebenaran dan kesabaran. (Ghazali A D, 2015)

Pada masa yang akan datang, agama tampaknya akan semakin dijadikan tumpuan harapan. Ia akan menjadi tempat kembali manusia-manusia modern yang mulai rindu terhadap nilai-nilai spiritualitas. Agama juga sangat diharapkan manjadi katalisator bagi terwujudnya perdamaian dunia yang hingga kini masih merupakan impian. (Safei A A, 2017: 138). 


\section{B. Utami,}

Dalam menyemangati keagamaan tentu tidaklah mudah hal ini karena banyak faktor yang mendukung maupun menghambat. Ada beberapa faktor yang mendukung dan penghambat diantaranya; (1)Tersedianya sarana prasana yang memadai, (2)Memiliki manajemen pengelolaan yang baik, (3)Adanya semangat pada diri jamaah, (4)Adanya komitmen dari ketua, anggota dan jamaah, (5)Adanya tanggung jawab.Sedangkan faktor penghambat menyemangati keagamaan diantaranya; (1)Saranan yang kurang memadai, (2)Dalam pengelolaan kegiatan cenderung kurang terkoordinir, (3)Jamaah kurang tesponsive dalam mengikuti kegiatan, (4)Tidak adanya kerjasama yang baik dari ketua, anggota dan para jamaah sendiri, (5)Kurang adanya tanggung jawab.

Wahyu pertama yang diturunkan Allah kepada Nabi Muhammad dalam (QS. Al-Alaq [96] : 1-5) menunjukan pentingnya arti belajar dalam kehidupan dan menuntut agar umat Islam untuk belajar dalam upaya untuk mencari ilmu terutama ilmu tentang keagamaan. Di samping itu, untuk memotivasi agar semangat menuntut ilmu agama, allah menjajinkan untuk memberikan tempat khusus bagi orang yang beriman dan berilmu. Orang yang berilmu memiliki tingkat ketakwaan yang lebih tinggi. Kenyataan ini dapat menjadi alasan untuk menyatakan bahwa menuntut ilmu khususnya ilmu agama itu hukumnya wajib.

Menurut Undang-Undang Republik Indonesia Nomor 40 Tahun 2009 tentang "Kepemudaan" menyatakan bahwa "pemuda adalah warga negara Indonesia yang memasuki periode penting pertumbuhan dan perkembangan yang berusia 16 (enam belas) sampai 30 (tiga puluh) tahun.

Pemuda adalah generasi yang dipundaknya dibebani berbagai harapan, terutama dari generasi yang akan datang. Hal ini dapat dipahami kerena pemuda diharapkan sebagai generasi penerus, generasi yang harus melangsungkan dan juga mengisi estafet pembangunan secara berkelanjutan (Mukhlis, 2007;1).

Dilihat dari segi pembangunan nasional, dimana hakekat dari pembangunan nasional adalah pembangunan Manusia Indonesia seutuhnya dan masyarakat seluruhnya, maka pemuda sebagai sumber potensi bangsa harus dibina dan juga dikembangkan dengan sebaik-baiknya, untuk menghantarkan pemuda-pemuda ke masa yang akan datang sebagai suatu generasi yang memiliki iman dan bertakwa kepada Tuhan Yang Maha Esa, mandiri, demokratis, kreatif, berakhlak baik, inovatif, cerdas, sehat, bertanggungjawab, dan mempuyai jiwa kepemimpinan, kepeloporan, kewirausahaan serta kebangsaan yang berlandasan Pancasila dan Undang-Undang Dasar Negara Republik Indonesia Tahun 1945 dalam kerangka Negara Kesatuan Republik Indonesia

Pemuda muslim, diciptakan untuk tetap konsekwen kepada konsepsi Robbani yang suci dari rona-rona kebatilan, baik yang datang dari depan maupun dari belakang. Pemuda muslim diperintahkan Allah untuk siap dipimpin dan loyal kepada-Nya. Karena misi besar yang di berikan Allah kepada pemuda muslim adalah memberlakukan hukum-hukum-Nya di seluruh kehidupan, baik 
untuk diri sendiri, keluarga dan masyarakat bahkan sampai penjuru dunia serta untuk mengalihkan manusia dari perhambaan terhadap sesamanya. Juga untuk membebaskan umat manusia dari alam yang sempit menuju alam bebas merdeka.Sehingga Islam sangat memperhatiakan para pemuda.

Untuk mewujudkan misi tersebut, pemuda muslim harus memiliki lima macam kriteria dan semua kriteria ini harus benar-benar diyakini sepenuhnya, yakni :(1) Iman yang kuat, harus menjaga hati agar iman tidak mudah surut dan goyah, (2) Keikhlasan yang sungguh-sungguh, keikhlasan yang tidak dibuat-buat atau riya, (3) Tekad yang kuat tanpa rasa takut, menyampaikan risalah-risalah Allah tanpa ada rasa takut kepada seorang pun kecuali kepada Allah, (4) Usaha yang berkesinambungan, tidak mengenal rasa jenuh dan malas.

Oleh sebab itu, bila mengikuti dinamika perkembangan sejarah dalam setiap dimensi, maka umat Islam akan mengatahui bahwa yang menjadi pengibar panji-panjinya, yang menjadi pilar penyangga kebangkitan Islam, serta menjadi panglima perangnya semua itu didominasi oleh tunas-tunas muda muslim yang sarat dengan iman. Pemuda Muslim yang dikatakan pemuda-pemuda beriman, dan untuk pemuda muslim Allah akan memberikan tambahan taufik dan hidayahnya.

Penelitian ini dilaksanakan di Komunitas Gerakan Pemuda Hijrah di pusat kota Bandung yang bermarkas di Masjid Al-Lathiif berada di Jalan Saninten No 2 Bandung Wetan, Kota Bandung, Jawa Barat 40114. Terbentuknya komunitas Gerakan Pemuda Hijrah berawal dari tujuh orang pemuda salah satunya adalah kang yang suka mencari tempat kajian ta'lim seperti di masjid-masjid di kota Bandung, dengan tujuan agar lebih dekat dengan Allah, salah satu masjid di kota Bandung yaitu masjid Al- Lathiif yang mengadakan kajian rutin di setiap hari Rabu Sore. Pada tahun 2012 mereka sedang mengikuti kajian ta'lim di Masjid Al-Lathiif jalan Saninten No 2 Bandung yang mengisi kajiannya adalah Ustadz Tengku Hannan Attaki. Lc, sebelumnya Ustadz Hannan Attaki sudah 8 tahun mengisi kajian di masjid Al- Lathiff yang jamaahnya hanya satu atau dua shaf saja, pada awalnya yang mengikuti kajian ta'lim Ustadz Hannan Attaki adalah para manula dan melihat dari tahun ketahun ada juga para pemuda yang mengikuti kajian, pada akhirnya Ustadz Hannan Attaki memberikan perhatian yang lebih terhadap para pemuda.

Berjalannya waktu mereka sering berkumpul dan berdiskusi dengan pemikiran yang sama. Mereka pun membuat sebuah acara yaitu "Brigez berdzikir", dan allhamdulilah sukses, setelah acara itu selesai, tercetuslah untuk membuat suatu gerakan di bidang dakwah yang aktor utamanya adalah para pemuda. Maka berdirilah gerakan dakwah yang bisa menarik perhatian para pemuda yang diberi nama Komunitas Gerakan Pemuda Hijrah atau sering disebut "Shift". 


\section{B. Utami,}

Komunitas Gerakan Pemuda Hijrah terbentuk pada tanggal 05 Maret 2015, dengan semangat usaha dan kerja keras dari anggota komunitas. Hingga saat ini menjadi tempat yang dapat menampung para pemuda yang ingin berhijrah, yang tidak hanya hijrah dengan menjadikan dirinya memiliki tanda di kening, berjanggut dan memakai gamis panjang tetapi hijrah untuk memperbaiki diri dan lebih dekat dengan Allah agar menjadi pribadi yang lebih baik.

Makna dari kata SHIFT adalah berasal dari bahasa Inggris yang artinya ber-alih atau pindah. Pada saat terciptanya komunitas Islam ini yang diberi nama SHIFT dan kata Pemuda Hijrahnya hanya sebuah tagline kecil saja. Namun pada saat ini masyarakat khususnya para pemuda lebih pengetahui atau lebih kenal dengan sebutan Pemuda Hijrahnya. Pada awal berdirinya komunitas Islam ini ketujuh pemuda tidak memakai istilah hijrah, karena terlalu berat mengemban amanah sebab tidak ada yang belakang pesantren. Dengan bantuan serta arahan dari Ustadz Hannan kemudian para pemuda tersebut bisa menjalani tanggung jawab dan amanah yang diberikan untuk mengajak pemuda khususnya di Kota Bandung untuk kembali kepada jalan yang lebih baik dan amar ma'ruf nahyir mungkar. (Wawancara dengan ketua Komunitas Gerakan Pemuda Hijrah: Kang Inong, 16 Januari 2018)

Agar luang ringkup cangkupan dakwahya tidak terlalu luas, dan ada batasan serta tujuan yang harus di capai oleh komunitas maka komunitas ini diberi nama Gerakan Pemuda Hijrah. Sebenarnya komunitas Geraka Pemuda Hijrah ini berkeinginan untuk merangkul semua kalangan masyarakat, namun melihat dari kemampuan setiap individu yang ada di komunitas Gerakan Pemuda Hijrah ini terbatas, maka cakupan dakwahnya pun hanya kepada para pemuda dan ada juga orang tua namun jumlahnya sedikit di banding dengan karangan muda. Walaupun begitu, pada akhirnya semua gerakan dakwah Islam memiliki tujuan yang sama yaitu untuk "kemenangan Islam", baik yang bersifat independent, organisasi maupun komunitas.

Komunitas Gerakan Pemuda Hijrah lebih di dominasi oleh para kaum laki-laki, maka dari yaitu penamaan komunitas ini lebih condong dengan kata pemuda. Hijrah disini maknanya adalah bergerak menuju sesuatu dengan meninggalkan sesuatu, jadi bukan hanya menuju tetapi juga meninggalkan, yang dituju adalah apa yang di perintahkan oleh Allah dan meninggalkan ada yang di larang olehnya. Pemuda yang dikatakan hijrah bukan hanya pemuda yang pada masa lalu memiliki pengalaman hidup yang kelam, tetapi pemuda yang sudah memiliki keinginan dan keyakinan untuk melepaskan sesuatu menuju sesuatu yang lebih baik.

Jumlah anggota di Komunitas Gerakan Pemuda Hijrah 250 orang, yang terdiri dari 50 penggerak yang bertugas membuat konten-konten dakwah, vidio, editing dll dan 200 di tarbiyah namun tidak aktif semua karena bermacam-macam profensi yang menjadi hambatan ketidak aktifan mereka dalam berbagai program 
komunitas Gerakan Pemuda Hijrah. (Wawancara dengan ketua Komunitas Gerakan Pemuda Hijrah: Kang Inong, 16 Januari 2018)

Komunitas Gerakan Pemuda Hijrah ini sebagai wadah bagi anak muda yang mau hijrah, pada saat waktu itu sebelum adanya pemuda hijrah banyak anak muda yang pengen hijrah tetapi tidak ada fasilitas khusus anak muda. Maka dari itu kami dan teman-teman yang dibimbing oleh Ustadz Hanan membentuk sebuah komunitas yang bisa menfasilitasi anak muda yang mau hijrah (Wawancara dengan ketua Komunitas Gerakan Pemuda Hijrah: Kang Inong, 16 Januari 2018)

Komunitas Gerakan Pemuda Hijrah merupakan sebuah komunitas pemuda yang memfasilitasi para anggota dan jama'ahnya untuk lebih dekat kepada Allah SWT. Di dalamnya terdapat banyak para Muslim dan Muslimah yang berhijrah atau berpindah dari kondisi yang sebelumnya belum mengenal Allah SWT kepada kondisi sekarang yang jauh lebih baik dan sudah mengenal Allah SWT.

Komunitas Islam adalah sebuah kelompok sosial dari beberapa individu Muslim dari berbagai latar belakang yang berbeda, yang pada dasarnya memilikitujuan dan ketertarikan yang sama untuk menyiarkan Islam. Dimana Individu-individu di dalamnya memiliki kepercayaan, maksud, kebutuhan, sumber daya, resiko, preferensi serta sejumlah kondisi lain yang sama. Komunitas berasal dari bahasa latin communitas yang berarti "kesamaan", kemudian diturunkan menjadi communis yang berarti "sama", publik dibagi oleh semua atau banyak. (Wenger E, 2002: 4).

\section{Kegiatan Komunitas Gerakan Pemuda Hijrah dalam Menyemangati Keagamaan para Pemuda}

Kegiatan yang telah dilakukan oleh Komunitas Gerakan Pemuda Hijrah dalam menyemangati keagamaan para pemuda, di menunjukan bahwa keberadaan Komunitas Gerakan Pemuda Hijrah memiliki kedudukan dan peranan yang sangat penting bagi para pemuda yang ingin hijrah atau memperdalam agama Islam. Pembinaan pada generasi muda sangat diperluakan agar para pemuda menjadi generasi muslim yang berakhlaq, beriman, bertaqwa, berilmu dan beramal shalih dalam rangka mengabdi kepada Allah SWT mencapai keridhaanNya.

Berdasarkan hasil wawancara yang dilakukan penulis kepada Kang Inong selaku ketua dan teh Diah selaku anggota Komunitas Gerakan Pemuda Hijrah, bahwa dalam menyemangati keagamaan para pemuda dilakukan dengan dua program kegiatan yang menjadi konsentrasi komunitas Gerakan Pemuda Hijrah yakni; (1) program internal dan (2) program eksternal.

Program internal sendiri fokus pada pendidikan anggota terhadap 


\section{B. Utami,}

pemahaman Islam lebih jauh lagi, untuk mereka yang telah tumbuh kecintaannya pada Islam, maka disediakan wadah yaitu tarbiyah, tarbiyah disini merupakan sebuah fasilitas bagi anggota Komunitas Gerakan Pemuda Hijrah yang ingin berjuang bersama membangun kehidupan Islam di dalam jiwa para pemuda. Tarbiyah dibagi menjadi 2, ada tarbiyah satu dan dua. Tarbiyah satu untuk anggota Komunitas Gerakan Pemuda Hijrah yang sudah lama bergabung atau angkatan pertama 2015, dan tarbiyah dua yang baru bergabung tahun 2017 baik ikhwan ataupun akhwat. Ikhwan dan akhwat dipisah dalam semua kegiatan internal ini. Kegiatan tarbiyah akhwat satu diadakan setiap hari Sabtu jam 15.00 dan tarbiyah dua setiap minggu jam 09.00 yang mengisi kajiannya umi Hanen dan umi Aisyah tentang akhlak dan tauhid adapun kang Inong yang lebih membahas tentang pergerakan. Sedangkan tarbiyah ikhwan diadakan setiap malam senin dan selasa yang mengisi kajiannya Ustadz Hanan, Abi Diky dan kang Inong yang lebih membahas tentang pergerakan.

Program eksternal, menyediakan fasilitas untuk pemuda yang ingin hijrah dan ingin memperdalam ilmu agama, agar dapat menumbuhkan rasa kecintaannya terhadap Islam. Diantaranya adalah kegiatan: yang pertama,Kajian Rutin Komunitas Gerakan Pemuda Hijrah.Kajian rutin yang diadakan yaitu sama halnya seperti kajian-kajian yang sering diadakan oleh suatu majlis ta'lim atau suatu organisasi lain pada umumnya. Namun yang membedakan kajian Gerakan Pemuda Hijrah dengan yang lainnya adalah suasananya. Suasana yang dibangun oleh tim Pemuda Hijrah pada saat ini lebih bersifat "kekinian" dalam arti dari segi pembahasannya, cara penyampaian materinya, hingga penampilan sang Ustadz dan membawa acara yang menyesuaikan pada saat ini. Kajian ini dilaksanakan setiap hari Rabu, Kamis dan Sabtu oleh para Ustadz-Ustadz muda seperti Ustadz Hannan Attaki, Ustadz Evie Efendi, Ustadz Imam Nuryanto, Ustadz Yusuf Burhannuddin, Ustadz Bawazier, Ustadz Rizal Abu Mikyal, Ustadz Lukman Nurhakim dan masih banyak lagi.Untuk kajian Kamis dan Sabtu biasanya dilakukan di masjid Al-Lathiif. Khusus hari Rabu diadakan di masjid Agung Trans Studio Bandung karena jamaah yang membeludak bisa dua sampai empat kali lipat dari kajian pada hari Kamis dan Sabtu. Bisa dikatakan kajian hari Rabu ini adalah prodaknya Pemuda Hijrah. Semua kajian di Komunitas Gerakan Pemuda Hijrah ini bisa dilakukan secara online dan offline.

Seorang da'i pun harus memiliki kemampuan diri seperti pengetahuan Islam yang bersumber dari Al-Qur'an, Sunnah dan juga ilmu-ilmu keislaman lainnya, pengetahuan bahasa dan kesastraan, memahami karakter objek dakwah, memahami dasar dakwah, memahami tujuan dakwah, materi dakwah yang akan disampaikan kepada mad'u secara benar dan baik, dan metode dakwah dengan menggunakan metode dakwah yang sesuai dengan kemampuan dirinya dan dengan materi yang diberikan serta dengan situasi dan juga kondisi yang lebih relevan dengan objek yang dihadapi (Sukayat T, 2015: 102). Seorang da'i juga 
harus memahami psikologi remaja apalagi yang menjadi sasaran dakwahnya para kawula muda (Ratnawati, 2016). .

Kegiatan, kedua Ladies Day adalah suatu kajian yang diadakan oleh Gerakan Pemuda Hijrah yang di khususkan untuk para pemudi (wanita) yang di laksanakan setiap hari Sabtu atau Minggu jam delapan pagi oleh Ustadzah Hannen. Mengenai materi-materi kajian yang disampaikan pun yakni seputar kajian seputar perempua.Perkembangan jamaah dari Ladies Day juga cukup pesatbisa mencapai 1000 orang setiap kajian sampai teras masjid Al-Lathiif.

Kegiatan, ketiga Qiyamul lail yang terkenal dengan sebutan Qiyam yang diambil dari bahasa Arab yang artinya mengikuti arti aslinya yakni bangun malam untuk melaksanakan ubadah-ibadah yang disunnahkan oleh Nabi seperti shalat tahajud, shalat hajat, shalat witir, tadarus Al-Quran dan ibadah-ibadah lainnya. Qiyamul lail sebagai salah satu kegiatan di komunitas Gerakan Pemuda Hijrah yang dilaksanakan pada hari Minggu pukul 02.00 WIB dini hari, dilakukan secara berjamaah hingga menjelang subuh. Setelah itu dilanjut tadarus berjamaah, para jamaah pun antusias dengan kegiatan ini, sampai-sampai keluar dari teras masjid saking banyak jamaah yang mengikuti kegiatan ini. Biasanya Qiyamul lail di pimpin oleh Ustadz Hanan, Ustadz Muzammil, Ustadz Pratama Yoga, Ustadz Zaenal Akbar, Ustadz Hasbyarrasyid dan Ustadz yang muda lainnya.

Kegiatan, keempat Maqomat merupakan suatu kajian yang lebih memokuskan pada cara-cara belajar irama dan lagam dalam melantunkan ayatayat suci Al-Quran atau yang terkenal dengan sebutan Qira'at, ada 7 macam jumlah maqomat yang ada, salah satunya adalah (1) maqomat bijar, (2) maqomat nahawand, (3) maqomat bayati, (4) maqomat kurdey. Dari keempat maqomat tersebut yang sering digunakan dalam kegiatan maqomat learning, karena lafalnya yang tidak terlalu sulit serta cocok dengan pelafalan lidah orang Indonesia, kegitan tersebut dilaksanakan setiap hari Jum'at ba'da Magrib oleh Ustadz Muzammil.

Kegiatan, KelimaShiftUlin, Ulin berasal dari bahasa Sunda yang artinya main atau bermain. Kegiatan Shift Ulin sebagai ajang pengenalan bakat para pemuda yang memiliki keahliaan dibidangnya masing-masing seperti Skateboarder, Pelukis, sepedah, Disx Jakey dan lain-lain. Kegiatannya pada acara "Youth Tawhed Fest' yang dilakukan di pelantara Masjid Al-Lathiif pada tanggal 12 Juni 2015 silam, pada kegiatan malam harinya yaitu Shalat Tahajjud bersama dilanjut dengan mengaji Al-Qur'an.. Seperti slogan yang dibuat oleh komunitas Gerakan Pemuda Hijrah yakni "Banyak main, banyak pahala, sedikit dosa" dan "Taat tapi asyik".

Kegiatan, keenam tabligh akbar dengan tema-tema yang dapat membangun keimanan para pemuda. Kegiatan ini juga menjadi ajang berbagi (sharing) pengalaman dari setiap anggota komunitas Gerakan Pemuda Hijrah. Tujuan diadakan kegiatan ini selain untuk mengumpulkan seluruh pemuda dalam 


\section{B. Utami,}

satu tempat besar, tabligh akbar ini menjadi ajang silaturahmi antara komunitaskomunitas kepemudaan yang hadir.Acara tabligh akbar biasanya diadakan ketika ada perayaan hari-hari besar Islam (PHBI)

Kegiatan, ketujuh olahraga berjamaahyangdilaksanakan setiap hari minggu pagi, tujuannya selain melatih tubuh agar sehat lahir dan batin juga sebagai ajang silaturahmi antar satu sama lain. Walaupun namanya olahraga berjamaah namun tetap dibalut dengan suasana dakwah sebab slogan dari komunitas Gerakan Pemuda Hijrah ini adalah "Banyak main, banyak pahala, sedikit dosa" dan "Taat tapi asyik".

Kegiatan, kedelapan tahsin Al-Quran sudah rutin dilakukan sejak berdirinya Komunitas Gerakan Pemuda Hijrah dan pada saat bulan Juli 2017 berkerja sama dengan Pusdiqu (Pusat Studi Quran) Al-Lathif. Tujuan utamanya adalah agar para pemuda dapat membaca Al-Quran dan menghapal Al-Quran, dengan pengarahan dari Ustadz Atep yang berprofensi sebagai Disc Jokey, Ustadz Hasbyar Rasyid. Pelaksanaanya setiap hari Kamis ba'da Maghrib, dan setiap malam Sabtu. Paara pemuda diarahkan dengan seksama sampai betul-betul mahir membaca dan menghapal Al-Quran.

Kegiatan, kesembilan Shift Giving Everyday merupakan program baru di tahun 2018 yang di mulai pada bulan Januari awal, tujuannya memberikan suguhan ilmu yang bermanfaat baik berupa jasa, ilmu, pelayanan dan produk serta untuk membuat anak-anak muda semangat pergi ke Masjid dintaranya kegiatan; (1)pemeriksaan kesehatan gigi, (2) penggobatan bekam archery coaching, (3) kursus make up kecantikan dan workshop startup bisnis, (4) materi self branding, (5) free coffee(6) kursus fotografi, (7) kursus design grafis, (8) potong rambut gratis untuk para ikhwan, (9) Bimbel Mafikibi untuk anak-anak SMP dan SMA, (10) kursus toefl, (11) workshof digital markrting, (12) coaching clinic sepak bola dengan Eka Ramdani. Dan kegiatan yang sampai saat ini masih berjalan adalah free coffee, di free coffe ini parabisa belajar bareng membuat coffee, dan menikmati coffe secara gratis sebab hanya membayar dengan senyuman.

Kegiatan, kesepuluh kegiatanselama bulan ramadhan seperti : (1) kegiatan ramadhan di markas atau pesantren kilat bagi pemuda, (2) kedua adalah iftor dan sahur gratis, (3) taraweh bersama dan qiyamulallaildi 10 hari terakhir yang di imami oleh Ustadz muda, seperti Ustadz Hanan, Ustadz Muzammil, Ustasdz Rahmat Baequni dll, (4) ngabuburide.

Kegiatan, kesebelas buka bersama puasa sunah Senin dan Kamis ini dilaksanakan di markas Komunitas Gerakan Pemuda Hijrah yakni di Masjid AlLathif, kegiatan ini bertujuan agar para pemuda semangat pelaksanakan ibadah puasa sunah, saling bersilaturahmi, dan agar semangat pergi ke masjid. Komunitas Gerakan Pemuda Hijrah memberikan kurang lebih 200 porsi, yang berupa minuman, nasi, lauknya, agar-agar, gorengan, kue dan yang lainnya.

Kegiatan, keduabelas Teras Tahfidz ini Shift berkerja sama dengan Masjid 
Al-Lathif merupakan kegiatan baru di bulan Juli tahun 2018, tujuannya di adakan teras tahfidz ini untuk menyalurkan bakat anak muda yang ingin menghapal AlQuran dan menjadi imam muda. Ada tiga program yakni : (1) Stay (mondok), (2) Frelance, (3) Internal atau untuk anggota Komunitas Gerakan Pemuda Hijrah.Persyaratan untuk mengikuti kegiatan ini adalah untuk laki-laki, minimal usia 15 tahun, mengikuti tata tertib yang berlaku, memiliki semangat untuk menghapal Al-Quran, kominmen dalam menghapal Al-Quran, lancar membaca Al-Quran.

Dengan kegiatan-kegiatan yang dilaksanakan di Komunitas Gerakan Pemuda Hijrah, banyak para pemuda dan pemudi yang semangat pergi ke Masjid dan mereka semangat mempelajari ilmu keagamaan atau hijrah, sebab dengan ilmu keagamaan hidup akan terarah dan akan teratur sehingga terhindar dari perbuatan yang negatif.

Kegiatan dakwah adalah sebagai proses mengajak manusia kepada AlIslam yang dilakukan baik secara tulisan maupun secara lisan, serta bisa juga dengan aksi sosial Islam atau dengan perbuatan, baik dalam bentuk lembagalembaga Islam sebagai wadah untuk kegiatan mengajak yang dilakukan secara sinkronisasi, kordinasi, sistematisasi tindakan dan integrasi program dengan waktu yang tersedia dan sumber daya untuk mencapai sasaran dan tujuan dakwah Islam. (AS E\& Tajiri H, 2009:11).

\section{Faktor Pendukung Dan Penghambat Komunitas Gerakan Pemuda Hijrah Dalam Menyemangati Keagamaan Para Pemuda}

Komunitas Gerakan Pemuda Hijrah mempuyai peran yang sangat penting saat ini karena bagi para pemuda yang ingin dekat dengan Allah SWT. Sekarang ini banyak para pemuda dan pemudi yang berhijrah dari kondisi yang sebelumnya belum mengenal Allah SWT, kepada kondisi sekarang yang jauh lebih baik dan sudah mengenal Allah SWT, karena para pemuda semangat untuk mencari ilmu agama. Ada beberapa faktor pendukung dan penghambat peran yang dilakukan Komunitas Gerakan Pemuda Hijrah dalam menyemangati keagamaan para pemuda. Faktor pendukung adalah hal-hal yang membantu Komunitas Gerakan Pemuda Hijrah baik secara internal ataupun secara eksternal. Sedangkan faktor penghambat adalah hal-hal yang menghambat peran Komunitas Gerakan Pemuda Hijrah dalam menyemangati keagamaan para pemuda baik secara internal ataupun eksternal.

Faktor pendukungInternal diantaranya; Pertama Street Outreach (Dakwah Jalanan). "Justru sebenernya lebih banyak selain kajian, salah satunya shift ulin, nah shift ulin ini banyak variannya dan sering, sebenenya kegiatan dakwahnya lebih banyak ulin. Karena main ini lah yang membuat kita berempati. Sekmen dakwah kita kan anak muda jadi harus gimana dakwah ke anak muda, kita harus 


\section{B. Utami,}

tahu perasaan anak muda apa, harus tahu maunya mereka apa, bahasa apa yang masuk untuk mereka, biar tahu kaya gitu gimana caranya, bergaul dengan mereka itu salah satu program kita banyak agenda-agenda main, kumpul sama anak komunitas apa, bikin acara keluar bareng sama komunitas apa, lebih banyak itunya".( Wawancara dengan ketua Komunitas Gerakan Pemuda Hijrah: Kang Inong, 16 Januari 2018)

Kegiatan Komunitas Gerakan Pemuda Hijrah selain Kajian dll. Kegiatan Ramadan dan yang lainnya.Kebanyakan ulin (main)dengan komunitas-komunitas seperti komunitas skateboard, vespa, sepedah, geng motor (Brigez dan XTC), Disx Jakey dan yang lainnya. Seperti yang sudah diketahui salah satu geng motor terbesar di Indonesia khususnya di kota Bandung yakni Brigez dan salah satu mantan anggota geng motor Brigez adalah Ustadz Evie Effendie yang sudah berhijrah dan bergabung dengan Komunitas Gerakan Pemuda Hijrah. Sebab Komunitas Gerakan Pemuda Hijrah ini menerima mereka yang ingin hijrah dengan apa adanya, baik mereka yang masih bertato, untuk membantu mereka menjadi lebih baik lagi. Dengan dakwah jalanan ini Komunitas Gerakan Pemuda Hijrah dapat diterima oleh anak-anak muda.

Faktor pendukung Internal, keduatema dakwah kekinian. "Sebelum Ustadz memberikan ceramah, kita selalu berdiskusi dulu mengenai isu-isu yang lagi hangat di bicarakan anak muda baik di dunia maya atau nyata teh setelah itu kita hubungkan dengan ceramah yang akan di sampaikan Ustadz". (Wawancara dengan anggota Komunitas Gerakan Pemuda Hijrah; Teh Diah, 23 Mei 2018).

Sebelum memberikan ceramah, Ustadz hanan dan yang lainnya terlebih dahulu di berikan briefing dengan anggota Pemuda Hijrah mengenai isu-isu yang sedang hangat dibicarakan di lingkungan anak muda saat ini ataupun para Ustadz terlebih dahulu mencari bait-bait atau informasi tentang apa yang belakangan menjadi pembicaraan masyarakat di dunia maya, yang nantinya kemudian isu-isu tersebut di kaitkan dengan ceramah yang akan disampaikan. Inilah salah satu daya tarik anak bagi para jamaah khususnya jamaah anak muda atau remaja, sang Ustadz kerap membahas tentang status single, mencari karir yang kebanyakan dialami oleh para jamaah.

Faktor pendukung Internal, ketiga bahasa dakwah yang mudah dipahami anak muda. "Ustandz muda khusunya Ustadz Hanan iya teh, rasanya membuat orang mudah terbawa untuk berhijrah, kata-katanya itu memang singkat tetapi penuh makna untuk kehidupan, mudah dipahami anak muda, sasarannya ke anak muda banget teh". (Wawancara dengan anggota Komunitas Gerakan Pemuda Hijrah; Teh Diah 23, Mei 2018).

Penampilan Ustadz yang menyesuaikan dengan para jamaah yang membuat suasana menjadi cair dan jamaah tidak sungkan. Bahasa- bahasa yang di gunakan saat menyampaikan ceramah pun menggunakan bahasa yang ringan dan masuk dikalangan anak muda serta bahasa-bahasa yang kekinian. Selain 
Ustadz Hanan ustadz yang lainnya pun seperti itu.

Ustad Handy Bonny misalnya, melakukan pengelolaan kesan dengan baik dan menghasilkan citra yang baik dihadapan publik. Ia menggunakan media sosial sebagai panggung dalam berdakwah dengan tema dan desain yang menarik. Ia juga berpenampilan “casual' sehingga mudah diterima oleh anak muda, juga bertingkah laku yang santun, santai, tidak menggurui, menggunakan bahasa yang ringan tetapi tetap menjaga etika dan kesopanan. Dengan mengetahui pengelolaan kesan pada da'i diharapkan pesan dakwah untuk menyeru ke jalan Allah lebih mudah tercapai.(Fatoni ,U. \& Rais,A.N., 2018).

Faktor pendukung Internal, keempat Fasilitas yang cukup memadai. Pelaksanaan kegiatan-kegiatan Komunitas Gerakan Pemuda Hijrah didukung oleh fasilitas yang cukup memadai. Fasilitas tersebut seperti tempat pengajian, tempat bermain dan yang lainnya. Dengan adanya fasilitas tersebut dapat membantu pelaksanaan kegiatan Komunitas Gerakan Pemuda Hijrah.

Faktor pendukung Internal, kelima kinerja anggota komunitas gerakan pemuda hijrah. "Posnya ada tapi yang ngisinya bergantian, sebenernya berlombalomba sih mereka, punya jiwa ingin berdakwah, ingin berbuat sesuatu untuk dakwah jadi mereka dengan suka rela mengeluarkan waktu dan tenaganya untuk berdakwah". (Wawancara dengan anggota Komunitas Gerakan Pemuda Hijrah; Teh Diah, 23 Mei 2018).

Semangat yang membara dari anggota Komunitas Gerakan Pemuda Hijrah dalam mengurusi semua keperluan Komunitas Gerakan Pemuda Hijrah dari mulai membuatan poster, vidio, editing, poto dan yang lainnya. Kinerja yang baik dan sesuai dengan bidangnya masing-masing menjadi poin penting.

Faktor pendukung Internal, keenam Dakwah melalui Media Sosial. "Salah satu elemen yang terlihat sekarang yaitu lewat kajian tapi kajian ini ada online dan offline, itu yang isti liat di instagram, one Minute Booster, yang di kajian itu bisa di bilang follow up dari tren yang di lihat di media sosial nahh kan orang sroll instagram ini ada di dengerin dia suka, mensen ke temennya dan pengen liat langsung”. (Wawancara dengan ketua Komunitas Gerakan Pemuda Hijrah: Kang Inong, 16 Januari 2018).

Komunitas Gerakan Pemuda Hijrah ini, untuk menarik perhatian para pemuda dengan menggunakan media sosial seperti Instragram Pemuda Hijrahdengan 1,5 M pengikut, Youtube Pemuda Hijrahdengan 153.004 subscriber, Facebook Pemuda Hijrah, Instragram Ustadz Hanan Ataki dengan 3,7 M pengikut. Dengan tema yang menarikdan poster, vidio yang unik sehingga menarik perhatian para jamaah. Lewat vidio one minutes booster dan kajian yang bisa di lihat secara online ataupun offline. Karena dengan metode dakwah dengan menggunakan sosial media, dakwah bisa dilakukan dimana saja tidak mesti di tempat yang sama, dan jika para jamaah mempunyai pekerjaan atau 


\section{B. Utami,}

kesibukan yang tidak bisa di tinggalkan, maka akan tetap bisa mengikuti kajiankajian dari Pemuda Hijrah tanpa harus datang ke lokasi kajian berlangsung dan juga tidak meninggalkan pekerjaan yang ada.

Faktor pendukung Internal, ketujuhPendanaan merupakan salah salah satu faktor pendukung, pendanaan Mandiri ini berasal dari para jamaah dan untuk jamaah juga. Cara itu dilakukan dengan adanya celengan yang di kelilingkan di setiap kegiatan, ada juga yang melalui rekening ke yayasan Pemuda Hijrah, biasanya yang melalui rekening untuk kegiatan donasi yang dilakukan bila ada bencana alam, Suriah dan untuk buka puasa sunah Senin dan Kamis.

Faktor pendukung Internal, kedelapan Penampilan Ustadz yang Menarik para Pemuda. "Banyak diantara temen-temen ketika diajak untuk ikut pengajian, mereka merasa takut dan malu duluan, karena melihat penampilan Ustadz yang memakai gamis panjang lengkap dengan sorban dan kopiah dan juga mereka merasa akan dicerahami dengan dalil-dalil Al-Quran. Maka dari itu saya dan teman-teman berdiskusi dengan Ustadz Hanan agar para pemuda tidak takut duluan dan hasilnya seperti teteh liat sendiri kalau Ustadz ceramah pakeannya seperti anak muda". (Wawancara dengan ketua Komunitas Gerakan Pemuda Hijrah; Kang Inong, 11 Januari 2018).

Saat menyampaikan ceramahnya Ustadz di Komunitas Gerakan Pemuda Hijrah mereka biasanya memakai kemeja flannel, kupluk, jaket kulit yang menjadi ciri khas ustadz di Komunitas Gerakan Pemuda Hijrah ini. Hal ini sematasemata dibuat agar para jamaah yang kebanyakan anak muda merasa nyaman ketika sedang menghadiri kegiatan Komunitas Gerakan Pemuda Hijrah

Faktor pendukung eksternal pertama adanya hubungan antara Komunitas dan Masyarakat yang cukup baik. Karena anggota Komunitas Gerakan Pemuda Hijrah terbuka dengan masyarakat di sekitar. Komunitas Gerakan Pemuda Hijrah ikut membantu masyarakat yang membutuhkan. Dampak dari hubungan baik itu mereka saling memberi dukungan seperti pada bulan Rammadan, masyarakat memberikan tajil kepada jamaah Komunitas Gerakan Pemuda dan masyarakat pun ikut dalam kajian, solat taraweh bareng, serta pada saat sholat idul fitri bersama masyarakat yang di laksanakan di luar Masjid Al-Lathif.

Faktor pendukung eksternal kedua, adanya semangat jamaah untuk mengikuti kegiatan Komunitas Gerakan Pemuda Hijrah. "Komunitas pemuda yang memiliki tujuan dakwah positif dengan cara yang mudah diterima kalangan pemuda masa kini, bahasa kajian pemuda hijrah sangat relevan dengan kehidupan beragama khususnya anak muda dan juga kajian ini bukan sekedar mendengar dan mencatat. Tapi bergaul dan bersosial, lebih bisa diterima oleh orang-orang yang baru mencoba seperti saya". (Wawancara dengan Jamaah: Teh Oca, 23 Mei 2018).

Semangat dari jamaah untuk menuntut ilmu agama di Komunitas Gerakan Pemuda Hijrah. Karena bahasa yang mudah di cerna dan tidak berat, tema-tema 
yang menarik perhatian anak muda, mereka pun bisa menambah teman dan Ustadz-ustadz muda yang merangkul anak muda untuk mengikuti semua kegiatan di Komunitas Gerakan Pemuda Hijrah khususnya kajian di hari rabu, karena pada hari Rabu jamaah selalu membeludak, biasanya tempat kajiannya pun berpindah-pindah seperti di Masjid Agung TSM, Masjid Pusdai, pernah juga di Masjid Istiqomah dan di Masjid-masjid di kampus-kampus (UNPAD, UNISBA, TELKOM DLL).

Salah satu bentuk semangat para jamaah dapat dilihat dari perkembangan jamaah dari tahun ke tahun awalnya kajian hari Senin dan Sabtu mencapai 400 lebih, dan hari Rabu 800 lebih sedangkan saat ini kajian hari Sabtu bisa mencapai 1000 orang dan kajian di hari Rabu bisa mencapai 4000 lebih orang. Di tahun ketiga ini kajian hari Senin di hapuskan.

Faktor pendukung Eksternal ketiga Lokasi yang Strategis. Lokasi Komunitas Gerakan Pemuda Hijrah atau yang sering disebut sebagai markas Komunitas Gerakan Pemuda Hijrah ini bertempat di Masjid Al-Lathif jalan Saninten No 2 Bandung. Tempatnya sangat strategis di tengah kota Bandung, dan mudah dilalui baik dengan kendaraan roda dua ataupun roda empat dan kendaraan umum. Selain di Masjid Al-Lathif, Komunitas Gerakan Pemuda Hijrah menggunakan Masjid-masjid di Kota Bandung seperti Masjid Trans Studio Bandung, Masjid Istiqomah, Masjid Pusdai dan Masjid di kampus-kampus khususnya dalam kegiatan kajian setiap hari Rabu. Hal tersebut menjadikan para jamaah banyak yang mengikuti kajian. Di liat dari sudut pandang geografis, Komunitas Gerakan Pemuda Hijrah ini masih bisa berkembang lagi.

Faktor penghambat Internal, pertama Pengelolaan SDM yang masih kurang memadai. "SDM karena masih banyak dari penggerak kita yang sifatnya palentir jadi ketika ada yang harus di kerjakan orangnya lagi ngak ada, misalnya mau bikin vidio tukang vidionya lagi kerja, mau bikin poto tukang potonya lagi ada orderan, dan rata-rata pas masih jomblo kerjanya bagus semangat udah nikah agak-agak ilang".( Wawancara dengan Ketua Komunitas Gerakan Pemuda Hijrah: Kang Inong, 11 Januari 2018).

Sumber Daya Manusia menjadi salah satu masalah di Komunitas Gerakan Pemuda Hijrah, karena diantara anggota khususnya penggerak yang memiliki kesibukan pekerjaan masing-masing dan sudah menikah, sehingga kurang terfokuskan untuk komunitas, yang mengakibatkan tugas-tugas tidak sesuai dengan rencana.

Faktor penghambat Internal, kedua dana. Sama seperti di dalam faktor pendukung, yakni masalah dana, karena apabila dana masih kurang maka kegiatan Komunitas Gerakan Pemuda Hijrah akan sedikit terkendala dan mengakibatkan terhambat.

Faktor penghambat Internal, ketiga kurangnya pemahaman di dalam 


\section{B. Utami,}

Komunitas Gerakan Pemuda Hijrah yang mengakibatkan terhambat dalam kegiatan-kegiatan, karena di dalam sebuah komunitas terdiri dari beragam sumber daya manusia yang memiliki keunikan masing-masing, status sosial, aspek psikologis dan latar belakang yang berbeda-beda. Untuk itu di butuhkan komunikasi yang baik agar tercapai kerjasama, bersinergi dan harmonis agar tercipta pemahaman di antara anggota komunitas.

Faktor penghambat Eksternal, pertama Sulit mencari tempat parkir terutama bila ada kegiatan di markas atau di Masjid Al- Lathif, karena lahan parkir sangat sedikit sekali, sebab Masjid Al-Lathif berada di tengah-tengah kompleks warga. Sampai-sampai para jamaah harus ikut parkir di garasi atau di depan rumah warga, dan bila kajian di Masjid Trans Studio Bandung pun sulit untuk mencari tempat parkir, para jamaah mengaku bila parkir di dalam Trans Studio Bandung itu aman tetapi biaya parkirnya lumayan mahal, dan ada juga jamaah yang parkir di Indomaret, rumah-rumah warga yang menediakan parkir dadakan.

Faktor penghambat Eksternal, kedua Jamaah kurang focus.Karena jumlah jamaah yang banyak sekali khususnya dalam kegiatan kajian di hari Rabu yang biasanya di laksanakan di masjid TSB yang mana didalam masjid sudah tidak tertampung sehingga sampai luar dan area parkir bis pariwisata pun penuh, bila hujan jamaah yang berada di luar kurang fokus dan ada juga beberapa jamaah yang datang hanya untuk bertemu teman dan mengobrol di belakang, akibatnya jamaah yang lain tidak fokus.

Faktor penghambat Eksternal, ketiga salah satunya ada beberapa orang yang tidak suka dengan cara berdakwah Komunitas Gerakan Pemuda Hijrah, salah satunya cara dalam menyampaikan materi-materi dengan bahasa diksi. Dan meraka menganggap Komunitas Gerakan Pemuda Hijrah ini tidak sesuai dengan sunah-sunah yang di ajarkan nabi.

Faktor penghambat Eksternal, keempat Kebijakan menjadi salah satu penghambat dalam kegiatan- kegiatan Komunitas Gerakan Pemuda Hijrah terutama dalam kegiatan bermain atau shift ulin, karena Komunitas Gerakan Pemuda Hijrah memiliki rencana untuk membuat ruang bermain untuk anak muda di tanah sebelah namun masih terkendala perizinan dan ada campur tangan. Ada beberapa orang mengganggap dakwah Komunitas Gerakan Pemuda Hijrah ini hanya main-main dalam arti tidak serius.

Dalam menyemangati keagamaan tentu tidaklah mudah hal ini karena banyak faktor yang mendukung maupun menghambat. Ada beberapa faktor yang mendukung dan penghambat diantaranya; (1)Tersedianya sarana prasana yang memadai, (2)Memiliki manajemen pengelolaan yang baik, (3)Adanya semangat pada diri jamaah, (4)Adanya komitmen dari ketua, anggota dan jamaah, (5)Adanya tanggung jawab.Sedangkan faktor penghambat menyemangati keagamaan diantaranya; (1)Saranan yang kurang memadai, (2)Dalam pengelolaan 
kegiatan cenderung kurang terkoordinir, (3)Jamaah kurang tesponsive dalam mengikuti kegiatan, (4)Tidak adanya kerjasama yang baik dari ketua, anggota dan para jamaah sendiri, (5)Kurang adanya tanggung jawab (Robiatun, 1995).

Sebagai alat analisis untuk melihat posisi pola dakwah yang dimiliki pola gerakan dakwah pemuda hijrah, apakah berada dalam tiga pola gerakan dakwah sebagaimana Moh. Tahir atau termasuk pola gerakan dakwah baru. Pola gerakan dakwah menurut Moh. Tahir meliputi: Pertama, gerakan dakwah sintetik yang menggabungkan antara budaya popular yang profane dengan tradisi popular yang dianggap Islami di tengah masyarakat. Kedua, gerakan dakwah yang berorientasi pada pembenahan internal dari actor-aktor dakwah dalam bentuk keterlibatan anak-anak muda dalam pengajian-pengajian bergenre tasawwuftarekat. Ketiga,model gerakan dakwah melalui jalur structural yang menitikberatkan pada konsep 'amar ma'ruf nahi mungkar'. Konsep gerakan dakwah yang ideal sebagaimana dipersepsikan oleh kalangan anak muda dari ketiga model gerakan dakwah di atas dapat dilihat sebagai garis rentang di mana terdapat gerakan dakwah yang sintetik di satu titik dan gerakan dakwah sebagai sebuah gerakan yang murni religious dan bersifat onkompromistik di titik yang lain. (Tahir, 2017). Tampaknya pola gerakan dakwah lebih menyerupai pola gerakan yang pertama.

\section{PENUTUP}

Berdasarkan hasil penelitian dan pembahasan tentang peran Komunitas Gerakan Pemuda Hijrah dalam menyemangati keagamaan para pemuda, maka dapat diambil kesimpulan sebagai berikut:

Pertama, Komunitas Gerakan Pemuda Hijrah sebagai komunitas Islam yang memiliki kedudukan dan peranan yang sangat penting bagi para pemuda yang ingin hijrah. Pembinaan pada generasi muda sangat diperluakan agar para pemuda menjadi generasi muslim yang berakhlaq, beriman, bertaqwa, berilmu dan beramal shalih dalam rangka mengabdi kepada Allah SWT mencapai keridhaan-Nya. Komunitas Gerakan Pemuda Hijrah dalam menyemangati keagamaan para pemuda dilakukan dengan dua program kegiatan yang menjadi konsentrasi komunitas Gerakan Pemuda Hijrah yakni; (1) program internal dan (2) program eksternal. Program internal sendiri fokus pada pendidikan anggota terhadap pemahaman Islam lebih jauh lagi, untuk mereka yang telah tumbuh kecintaannya pada Islam, maka disediakan wadah yaitu tarbiyah. Sedangkan program.

Program eksternal, menyediakan fasilitas untuk pemuda yang ingin hijrah dan ingin memperdalam ilmu agama, agar dapat menumbuhkan rasa kecintaannya terhadap Islam, diantaranya kajian rutin rabu dan malam minggu, 


\section{B. Utami,}

ladies day, qiyamullail, maqomat learning, shift ulin, tabliqh akbar, olahraga berjamaah, tabsin Al-Quran, shift giving everyday, kegiatan ramadan, buka bersama puasa sunah dan teras tabfid\%:

Kedua, faktor pendukung dan penghambat Komunitas Gerakan Pemuda Hijrah dalam menyemangati keagamaan para pemuda. Fakor pendukung diantaranya dakwah jalanan, dakwah melalui sosial media,tema dakwah kekinian, penampilan ustadz menarik anak muda, fasilitas cukup memadai, kinerja anggota baik, pendanaan, semangat jamaah, lokasi strategis, hubungan dengan masyarakat cukup baik. Faktor penghambat diantaranya pengelolaan sumber daya manusia masih kurang, dana, kurang pemahaman anggota, sulit mencari tempat kajian, sulit mencari tempat parkir, jamaah kurang fokus, Ada yang tidak suka dengan cara berdawah Shift, dan kebijakan.

Setelah melakukan penelitian terhadap kegiatan-kegiatan yang ada di Komunitas Gerakan Pemuda Hijrah dalam menyemangati keagamaan para pemuda, alangkah baiknya apabila:

Pertama, dalam menyusun struktur kepengurusan Komunitas Gerakan Pemuda Hijrah, hendaknya melakukan pembagian tugas yang jelas, dengan menempatkan posisi pengurus dan anggota sesuai dengan bidangnya masingmasing. Agar semua kegiatan dapat berjalan dengan baik dan sesuai dengan harapan.

Kedua, menjalin kerjasama dengan Komunitas-komunitas Islam lainnya.

Ketiga, kepada masyarakat sekitar Masjid Al- Lathif agar tetap menjaga nama baik Komunitas Gerakan Pemuda Hijrah.

\section{DAFTAR PUSTAKA}

AS E. (2011). Pengembangan Masyarakat Islam dalam Sistem Dakwah Islam. Dalam Ilmu Dakwab: Academic Journal for Homiletic Studies, 5(18), 469-482.

Baier, D. (2013). The Influence of Religiosity on Violent Behavior of Adolescents: A Comparison of Christian and Muslim Religiosity. Journal of Interpersonal Violence, 29(1).

Clara Eggera and Raul Magni-Berton. (2019). The Role of Islamist Ideology in Shaping Muslims Believers' Attitudes toward Terrorism: Evidence from Europe. STUDIES IN CONFLICT \& TERRORISM, 1-24.

Fatoni, U. \& Rais,A.N. (2018). Pengelolaan Kesan Da’i dalam Kegiatan

Dakwah Pemuda Hijrah. KOMUNIKA: Jurnal Dakwah dan Komunikasi, 12(2), 211-222.

Ghazali A D.( 2015). Studi Islam. Bandung: PT Remaja Rosdakarya. Ikbar, Y. (2012). Penelitian Sosial Kualitatif. Bandung: Refika Aditama. Kahmad, D. (2006). Sosiologi Agama. Bandung: PT Remaja Rosdakarya. 
Mansur et.all. (2018). Implementation of Islamic Education in Promoting Religious Awareness for High School Students in Kendari. ICon-ITSD IOP Publishing IOP Conf. Series: Earth and Environmental Science ,175, 1-7.

Moleong, L.J. (2000). Metodologi Penelitian Kualitatif. Bandung: Remaja Rosdakarya.

Ratnawati (2016). Memahami Perkembangan Jiwa Keagamaan Pada Anak Dan Remaja. Fokus : Jurnal Kajian Keislaman dan Kemasyarakatan, 1(1), 1-32.

Rosihon. (2010). Akblak Tasawnf. Bandung: Pustaka Setia. Media.

Safei A A. (2017). Sosiologi Islam: Transformasi Sosial Berbasis Taubid. Bandung: Simbiosa Rekatama.

Safei A A. (2016). "Develooment of Islamic Society Based on Majelis Ta'lim: A Study of the Shifting Role of the Majelis Ta'lim in West Java". American Journal of Applied Sciences, 13 (9), 947-952.

Shihab Q M. (1996). Wawasan al-Quran. Bandung: Mizan.

Sukayat, T. (2015). Ilmu Dakwah. Bandung: Simbiosa Rekatama Media.

Tahir, M. (2017). Dakwah Islam di Kalangan Anak Muda di Kota Samarinda. Jurnal Pemberdayaan Masyarakat: Media Pemikiran dan Dakwah Pembangunan, 1 (2), 257-280.

Wenger, E.(et.al). (2002). Cultivating Communities Of Practice: A Guide ToManaging Knowledge [Terjemahan]. Boston: Harvard Business School Press. 